\title{
Municipal solid waste management in Aba, Nigeria: Challenges and prospects
}

\author{
Ezerie Henry Ezechi ${ }^{1^{\dagger}}$, Chima George Nwabuko ${ }^{2}$, Ogbonna Chidi Enyinnaya ${ }^{2}$, \\ Chibunna John Babington ${ }^{2}$
}

${ }^{1}$ Department of Civil and Environmental Engineering, Universiti Teknologi PETRONAS, 32610, Bandar Seri Iskandar, Perak, Malaysia

${ }^{2}$ Department of Environmental Resource Management, Abia State University, P.M.B 2000, Uturu, Nigeria

\begin{abstract}
Solid waste disposal and management is a critical problem in Nigeria. Annually, a huge quantity of municipal solid waste is generated in Aba. Municipal solid waste disposal in Aba poses severe challenge to environmental safety, public health and welfare of citizens. The situation is made worse by the indiscriminate dumping of refuse at roadsides, streets, waterways and empty lands. The impact of this waste management practice in Aba is environmental deterioration. Efforts to improve waste management in Aba have not recorded significant success. This paper therefore aims to highlight the challenges facing the waste management sector in Aba and proffer solutions on how to improve the sector.
\end{abstract}

Keywords: Aba, Composting, Incineration, Landfilling, Municipal solid waste management

\section{Introduction}

Municipal solid waste management (MSWM) is the process of collecting, storing, treatment and disposal of solid waste in such a manner that they are harmless to humans, plants, animals, ecology and the environment in general [1]. In developed nations, waste management have evolved into material flow management which involves careful handling of raw materials, reduction of green gas emissions, environmental protection, job creation and revenue generation. In contrast, waste management in developing nations is still at infancy and faces numerous challenges.

Municipal solid waste generation can be influenced by several factors such as economic development, income level, industrialization, urbanization, human attitude and local climatic conditions [2]. In Nigeria, municipal solid waste (MSW) can be classified based on its origin. For instance in Aba, MSW can be classified into;

i . Domestic waste (waste from households, food centers, markets, and commercial premises)

ii. Industrial waste (excluding toxic waste that requires special handling)

iii. Institutional waste (waste from government establishments, schools, hospitals and recreational facilities)

Despite numerous efforts by Abia State Environmental Protection Agency (ASEPA) to improve waste management in Aba, there are several impediments which challenge their efforts. The common practice for waste management in Nigeria is landfilling (open dumping) [1]. Substantial quantity of solid waste generated in Aba metropolis are indiscriminately deposited on roads or roadsides, unapproved dumpsites, in water ways (drainage system) or in open sites which negatively impact the environment and de-beautify its landscape [3]. Some of the open dumps are indiscriminately located at streams, valleys, water lands, open fields and abandoned borrow-pits [3]. This system of waste disposal accumulates huge quantity of waste annually and is associated with several problems such as contamination of groundwater and outbreak of various human diseases [4].

In Aba, experimental studies have shown that about $47.39 \%$ of the total solid waste is organic and compostable whereas recyclable waste accounts for about 4.69-9.90\% [5]. Improper disposal of these untreated wastes can be deleterious. Air pollution, underground water contamination, land degradation, soil contamination and habitat deterioration can be caused by improper waste disposal
This is an Open Access article distributed under the terms of the Creative Commons Attribution Non-Commercial License (http://creativecommons.org/licenses/by-nc/3.0/) which permits unrestricted non-commercial use, distribution, and reproduction in any medium, provided the original work is properly cited.
Received August 3, 2017 Accepted September 5, 2017

${ }^{\dagger}$ Corresponding author

Email: honhenry2k5@gmail.com

Tel: +60-165455924 Fax: +60-53676552

Copyright (C) 2017 Korean Society of Environmental Engineers 
[2]. Environments close to dumpsites are constantly exposed to risk of infection, reduced agricultural yield, groundwater contamination, decline in benthic communities due to toxicity and exposure to hazardous compounds [3, 6]. Additionally, global warming, photochemical oxidant creation, acidification, ecotoxicity of water, eutrophication and abiotic resource depletion can be caused by indiscriminate dumping of waste [7]. According to the World Health Organization (WHO) and the United Nations International Children Education Fund (UNICEF), bad sanitation, decaying or non-existent sewage system and toilets fuels the spread of various diseases (cholera, diarrhea and basic illness) which kill a child in every 21 seconds [8].

The objective of this paper is to highlight some of the waste management techniques and compare the waste management strategy in Aba with other cities. It also highlights some of the challenges faced by the waste management sector in Aba and proffer solutions on how to improve waste management in Aba.

\subsection{The Demography of Aba}

Aba is located in Abia State, South East of Nigeria between latitude $5.07^{\circ} \mathrm{N} 7.22^{\circ} \mathrm{SE}$ and longitude $5.177^{\circ} \mathrm{N} 7.367^{\circ} \mathrm{E}$ [3]. The city has road connections leading to several other states such as Akwa Ibom, Imo, Ebonyi, Enugu and River States, respectively. The city is a commerce center and has Ariria International market which is considered the biggest market in West Africa. Additionally, the city has many manufacturing industries such as brewery, distillery and other famous food and beverage industries which generate huge amount of waste. There are discrepancies over the actual population of the city but the 2006 census by the National population commission (NPC) summed the figure at 936,821 for the four local governments (Aba North, Aba South, Osisioma and ObiNgwa) which make up Aba [9]. The city experiences two climatic conditions annually which are the dry and rainy season. The dry season (October-March) and the rainy season (April-September) vary due to seasonal changes. A harmatan period usually characterized by dusty wind and dry conditions starts from December to February, though it can vary [3]. Aba has an average mean temperature of $24-34^{\circ} \mathrm{C}$. Waste generation in Aba is estimated at 236,703 tons/mon. The municipality in charge of waste management in Aba is the ASEPA.

\section{Waste Management Techniques}

There are several techniques for waste management. Significant among them are incineration, landfilling, source reduction, recycling and composting. These techniques have been widely employed in waste management. However, these techniques have their merits and demerits.

\subsection{Incineration}

Incineration is a widely used waste management technology. The mechanism of incineration depends on the combustion of waste at high temperatures. Incineration has the capability to [10]:

i. Reduce total organic matter content

ii. Destroy organic pathogens or contaminants iii. Significantly reduce waste volume

iv. Preserve raw materials and resources

However, Incineration does not eliminate waste but reduce and transform it into new forms which also require disposal in landfills [11]. There are great concerns about incinerators due to aesthetic issues such as foul odors, noxious gases and gritty smoke. Additionally, air quality deterioration, toxicity, disposal of produced ash and potential leaching of heavy metals from fly ash are critical concerns about incineration [7]. In developing nations where waste composition is mainly organic, incinerators require the supply of excess fuel for waste combustion due to high moisture content of solid waste [12, 13]. According to Foo Tuan Seik, [14], waste management by incineration is estimated to cost about 7 times more than landfilling. Recycling of MSW is widely practiced in developed nations. Thus, it is widely acceptable that incineration may not be suitable for developing nations.

\subsection{Landfilling}

A landfill relates to an area designated for waste disposal in such a manner that it does not pollute the surrounding environment especially, groundwater. Landfills are used for a specific period of time. However, the use of landfill for waste management has become less sustainable due to the rising cost of construction, operation and environmental consequences [4, 11, 15]. For instance, methane emissions from landfills in Germany have previously accounted for about $25 \%$ of total methane emissions. Thus, disposal of highly organic waste into landfills were prohibited in 2001 [16]. Landfills produce leachate and gases which are harmful to both humans and natural systems. These landfill gases (LFGs) which are product of anaerobic decomposition of complex molecules contribute to urban ozone problems and global warming [7]. Some of the challenges of landfilling include [17]:

i. Shortage of dumping sites

ii. Strict environmental legislation

iii. Contamination of groundwater through leaching of leachate

Landfills could be classified into three categories namely open landfills, semi-controlled landfills and sanitary landfills. The challenges, health and environmental implications of open landfills are enormous and may not be suitable for developing countries. Although it is the common practice (open dumping) in developing countries, it's environmental and health implications are enormous. Therefore municipalities must put into consideration, the health and environmental concerns of their citizens and adopt approaches that will mutually serve the citizens and their government.

\subsection{Composting}

Composting is a microbial technology occasionally used to stabilize various type of waste. Composting can capably reduce waste volume by $40-50 \%$, metabolically destroy pathogens in the thermophilic phase and produce an end product suitable for soil amendment [18]. As a natural aerobic biochemical process in which thermophilic microorganisms decompose organic materials into a stable soil like product, composting eliminates payment of tipping fees at landfills and pathogens present in the waste do not survive the thermophilic temperature $\left(40-70^{\circ} \mathrm{C}\right)$ during composting [19]. 
Composting can be conducted using several approaches such as open aerated systems and contained systems. The benefits of composting biogenic waste include [20]:

i. Replacement of synthetic fertilizers

ii. Reduction in greenhouse gas emissions

The most significant challenge to composting of MSW is sorting/separation of waste. Municipalities must develop a strategy to separate the organic waste in order to produce good compost. Application of unstable and immature compost to agricultural soil can cause N starvation to plants [21], phytotoxic effects due to the emission of ammonia and other substances like phenolic compounds and low molecular weight organic acids [22], and the presence of pathogens [23]. To ensure the safety of compost in agricultural application, the maturity and stability have been used to define compost quality [24]. Therefore, composting of MSW may be viable for developing nations.

\section{Waste Management Strategies in Some Cities}

The MSW management techniques in most countries differ. Several indices such as waste type, waste characteristics, economy and available technology influence the choice of waste management technique. Some of the waste management techniques in some cities are discussed below.

\subsection{Castellon de la Plana, Spain}

The waste management technique in Castellon de la Plana, Spain is summarized by Bovea et al. [25]. The waste composition in Castellon de la Plana, Spain is mainly organic (57\%). The household waste collection is carried out through selective collection of waste at materials banks (glass, paper/cardboard and packaging) and street-side collection of the remaining waste. At the sorting plants (glass sorting plant, paper sorting plant and packaging separating plant), the collected waste is separated before recycling. The other waste categories are compacted at a transfer station (TS) and transported to the material recovery facility (MRF). The organic portion of the waste is composted whereas the remaining waste is recycled. The non-recyclables are then compacted in bales and disposed in a landfill without energy recovery.

\subsection{Chennai, India}

The MSW generation and management in Chennai, India is summarized by Arvind et al. [26]. The common MSW management technique in India is landfilling (70-90\% open dumpsites). Composting of a small fraction of the waste has been conducted in Delhi and Mumbai. The MSW generated from Chennai originates from residential, commercial, restaurant and industrial activities in the following proportion of $68 \%, 14 \%, 12 \%$ and $2 \%$, respectively. Healthcare wastes are disposed separately. There are two landfills in Chennai which are Kodungaiyur (KDG) and Perungudi (PGD) landfills. MSW collected from Zones 1-5 is deposited in KDG landfill whereas waste from zones 6-10 is deposited in PGD landfill.

\subsection{Palm Beach County, FL}

The MSW management in Palm Beach County, FL is summarized by Weitz et al. [27]. In the United States, MSW collection, transportation, recycling, composting, combustion and landfilling are well organized through sound technological advancements. In Palm Beach County, FL, several waste management facilities such as refuse derived fuel processing facility, ferrous processing facility, a material recovery facility and a co-composting facility are available to manage and convert the waste into useful end products. The sequence of waste management are recycling, composting and landfilling.

\subsection{Berlin, Germany}

The MSW management in Berlin, Germany is summarized by Zhang et al. [16]. In Berlin, the MSW management techniques are incineration and landfilling. The implementations of the 3Rs (reduce, reuse and recycle) significantly contributed to the success of MSW management in Germany. The improvement in the sorting and recycling of recyclable waste positively impacted the waste management sector. Some waste categories were prohibited from disposal into landfills. For instance, landfilling of untreated waste with high organic content was prohibited since June 2001 by the waste disposal act which specifically refers to domestic waste in Germany. As a consequence, several landfill sites were closed in Germany. The number of landfills reduced from 50,000 in 1970s to 333 in 2000. At present, there are only about 160 landfill sites still in operation nationwide and in Berlin, there are currently three landfill sites. This is because methane emissions from landfills in Germany have previously accounted for about $25 \%$ of total methane emissions. However, incineration of waste have increased in Germany from 7 incinerators with a capacity of 718,000 tonnes/y in 1965 to 72 incinerators with a capacity of $17,800,000$ tonnes/y in 2007 .

\subsection{Aba, Nigeria}

The MSW management technique in Nigeria is summarized by Abila and Kantola [28] and can be illustrated in Fig. 1.

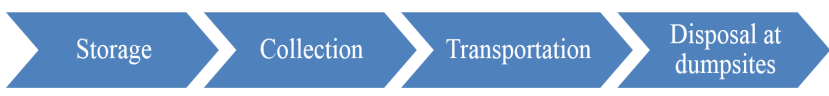

Fig. 1. Waste management strategy in Aba.

The poor state of waste management in Aba and Nigeria is caused by the weak implementation of the regional and national environmental policies designed to protect the environment, public health and natural resources [29]. The common MSW management in Aba is landfilling at open dumpsites. The system consists of storage, collection, transportation and disposal at open dumpsites. MSW in Aba are mixed up with no definite system for separation. The existence of legal and illegal dump sites in residential or commercial areas are worrisome as they produce odours, rodents and pollute the natural environment [6]. This system of waste management causes breeding of some disease vectors and pathogens, destroy the landscape and reduce the aesthetic value of the environment [3]. For instance, the Umuigwe Osisioma dumpsite receives up to 25 tons of waste daily as well as the Ogbor dumpsite. The composition of these waste include organic materials (food waste), car batteries, metals, plastics, industrial wastes and used papers [3]. The average mean temperature of $\mathrm{Aba}$ is about $24-34^{\circ} \mathrm{C}$ with a relative humidity of about $70 \%$ 
and $90 \%$ in dry and rainy periods, respectively [3]. Physicochemical analysis indicates that the composition of leachates from Umuigwe Osisioma and Ogbor dumpsites violates the Federal Environmental Protection Agency (FEPA) standards for some compounds such as biochemical oxygen demand (BOD), $\mathrm{pH}$, nitrate, manganese and iron [3]. The high concentration of these compounds indicates that the dumpsite undergoes natural decomposition since the waste is mainly domestic and organic in nature. High concentration of manganese and iron are undesirable and support bacteria growth in distribution system, add taste and color to water [3].

\section{Challenges of Effective Waste Management in Aba}

The choice of waste treatment technique considerably varies from one country to the other and significantly depends on several indices such as type of waste, availability of land for disposal and availability of technology [10]. The challenges of appropriate waste management in Aba are multifarious and typical of other developing nations [30]. Significant among them are poor environmental education and awareness, lack of suitable technologies, lack of incentive to recycling initiatives and poor funding of environmental agencies.

\subsection{Poor Environmental Education and Awareness}

The single greatest constraint to waste management in developing nations is poor environmental education and awareness [31]. In $\mathrm{Aba}$, the level of environmental education and awareness is low. This is the single greatest constraint to waste management in Aba. It is important for the government to overcome this constraint and implement successful programs that will enhance public knowledge of the environment. It is widely accepted that environmental education and awareness programs that produces enduring knowledge and commitment can transform the residents into an environmentally conscious people. Through these programs, residents can understand how the environment can affect and be affected by their actions [32]. These programs will enable the residents desist from indiscriminate dumping of refuse at illegal dumpsites, roadways, streets and public places. The government should intensify awareness program to educate and sensitize the residents on the need for proper waste management practice. Residents should take responsibility for their generated waste and be willing to pay the corresponding waste management fee. The government also must encourage the residents through steady and scheduled collection of waste.

\subsection{Lack of Suitable Technologies}

Lack of suitable technology is a great impediment to effective waste management in developing nations. This include insufficient equipment for collection, transportation and disposal of waste, poor knowledge and skill of existing technologies [33]. The most common waste management strategy in developing countries is landfilling in open dumpsites which do not require much expertise. The MSW composition in Aba is mainly organic and can be used for biogasification and compost. The government must encourage private sector involvement in waste management. Additionally, the government should invest in suitable technologies which can generate revenue, create jobs and protect public health and environment. Municipalities must demonstrate the capacity to implement and manage these technologies. With suitable technologies, resource recovery will be promoted.

\subsection{Lack of Incentives to Recycling Initiatives}

In some developed countries, incentives were used to motivate residents to recycle their waste products. This is significantly effective as it encourages the resident to sort and store their waste. In Aba, with the poor environmental awareness of residents towards waste management, issuing of incentives for recyclable waste will motivate residents to patronize the material recovery facilities. This will significantly influence waste generation and disposal.

\subsection{Poor Funding of Environmental Agencies}

In developing countries, lack of adequate resources and technical expertise hinder municipal corporations from proper execution of waste management [11]. Environmental agencies require adequate funding for the maintenance of garbage trucks, payment of salaries for staffs and public waste collectors and other logistics which can hinder effective waste collection and disposal. The consequences of inadequate funding are poor waste management services by the environmental agencies. Effective waste management should involve the participation of all stakeholders.

\section{The Way Forward}

There is a dire need for a total and immediate re-structuring of the waste management sector in Aba and its environs. Abia State government recently abolished the use of agents for revenue collection. This is a decision in the right track. A systemic billing system should be developed that allows residents to pay an affordable fee for waste management services directly to the government coffers. The government should intensify awareness programs aimed at encouraging primary sorting of waste at source by residents. The waste in Aba is mainly organic. The government should intensify efforts to implement technologies for resource recovery through

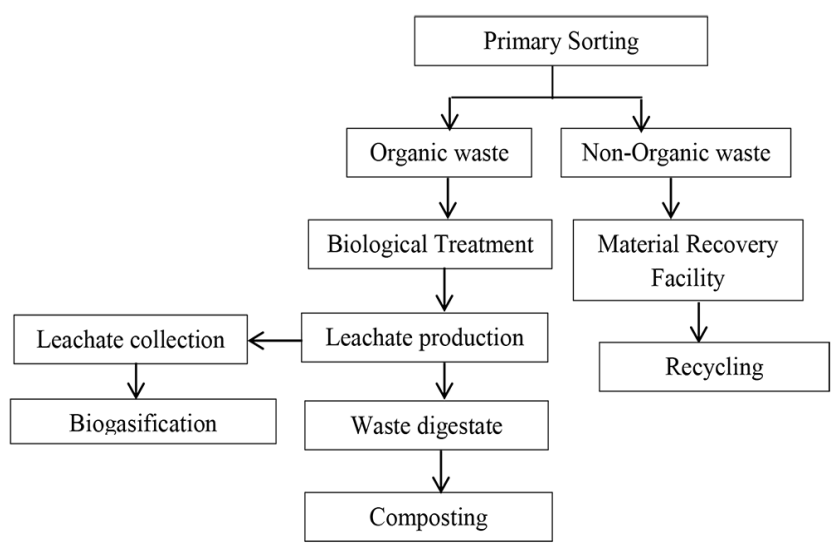

Fig. 2. Proposed framework for waste management in Aba. 
biogasification and composting. Biogasification can assist the poor energy status of Aba whereas composting of digestate can produce organic fertilizer for farmers. Both methods can generate revenue for the government. The proposed waste management strategy in Aba is illustrated in Fig. 2.

\section{Conclusions}

The high volume of solid waste generated in Aba metropolis alone can be put to beneficial use such as obtaining new products or deriving cleaner form of energy through waste to energy conversion. The value-added recycling of waste should be given precedence over open dumping of waste. Abia State's high material, labor, waste generation and business strength favors the economics of recovering, reuse and recycle towards resource management. It is therefore significant for the large quantity of organic waste materials generated in Aba to be efficiently managed through composting and biogasification in order to produce an end product that is useful in agriculture as well as revenue generation. The proposed framework is designed for sustainable development. It is therefore necessary for the government and all stakeholders to fully participate in waste management for greater goals.

\section{References}

1. Agwu MO. Issues and challenges of solid waste management practices in Port-Harcourt City, Nigeria - A behavioural perspective. Am. J. Soc. Manage. Sci. 2012;3:83-92.

2. Odoemene UD, Ofodu J. Solid wastes management in Aba Metropolis. Int. J. Adv. Acad. Res. 2016;2:1-7.

3. Ukpong ECU, Udo EA, Umoh IC. Characterization of materials from Aba waste dumpsites. Int. J. Eng. Appl. Sci. 2015;6:1-10.

4. Akor AJ, Ayotamuno MJ, Aman LI, Enokela SO. Assessment of domestic solid waste generation in PortHarcourt by separator - Receptacle technology. Int. J. Sci. Eng. Res. 2013;4:1-7.

5. Ajero C, Chigbo U. A study on the evaluation of industrial solid waste management approaches in some industries in Aba, South Eastern Nigeria. W. Afr. J. Ind. Acad. Res. 2012;4:103-112.

6. Ayuba KA, Manaf LA, Sabrina AH, Azmin SWN. Current status of municipal solid waste management practise in FCT Abuja Res. J. Environ. Earth Sci. 2013;5:295-304.

7. Nkwachukwu OI, Chidi NI, Charles KO. Issues of roadside disposal habit of municipal solid waste, environmental impacts and implementation of sound management practices in developing country "Nigeria". Int. J. Environ. Sci. Dev. 2010;5:409-418.

8. Momodu NS, Dimuna KO, Dimuna JE. Mitigating the impact of solid wastes in urban centres in Nigeria. J. Hum. Ecol. 2011;34:125-133.

9. National Population Commission [Internet]. 2006 PHC priority Table. c2016. Available from: http://population.gov.ng/core-activities/surveys/dataset/2006-phc-priority-tables/.

10. Sabbas T, Polettini A, Pomib R, et al. Management of municipal solid waste incineration residues. Waste Manage. 2003;23:61-88.

11. Narayana T. Municipal solid waste management in India: From waste disposal to recovery of resources? Waste Manage. 2009;29:
1163-1166.

12. Ogwueleka T. Municipal solid waste characteristics and management in Nigeria. J. Environ. Health Sci. Eng. 2009;6:173-180.

13. Zhang S, Herbell JD, Gaye-Haake B. Biodegradable organic matter in municipal solid waste incineration bottom ash. Waste Manage. 2004;24:673-679.

14. Seik FT. Recycling of domestic waste: Early experiences in Singapore. Habitat Int. 1997;21:277-289.

15. Ezechi EH, Isa MH, Kutty SR, Sapari NB. Boron recovery, application and economic significance: A review. In: National Postgraduate Conference (NPC); 19-20 September 2011; Kuala Lumpur, Malaysia. IEEE; 2011. p. 815-820.

16. Zhang D, Keat TS, Gersberg RM. A comparison of municipal solid waste management in Berlin and Singapore. Waste Manage. 2010;30:921-933.

17. Sharma S. Municipal solid waste management through vermicomposting employing exotic and local species of earthworm. Bioresour. Technol. 2003;90:169-173.

18. Singh R, Ibrahim MH, Esa N, Iliyana M. Composting of waste from palm oil mill: A sustainable waste management practice. Rev. Environ. Sci. Bio/Technol. 2010;9:331-344.

19. Schaub S, Leonard J. Composting: An alternative waste management option for food processing industries. Trends Food Sci. Technol. 1996;7:263-268.

20. Couth R, Trois C. Cost effective waste management through composting in Africa. Waste Manage. 2012;32:2518-2525.

21. Kato K, Miura N, Tabuchi H, Nioh I. Evaluation of maturity of poultry manure compost by phospholipid fatty acids analysis. Biol. Fertil. Soils 2005;41:399-410.

22. Bernal MP, Alburquerque J, Moral R. Composting of animal manures and chemical criteria for compost maturity assessment A review. Bioresour. Technol. 2009;100:5444-5453.

23. Fang M, Wong J, Ma K, Wong M. Co-composting of sewage sludge and coal fly ash: Nutrient transformations. Bioresour. Technol. 1999;67:19-24.

24. Moral R, Paredes C, Bustamante M, Marhuenda-Egea F, Bernal M. Utilisation of manure composts by high-value crops: Safety and environmental challenges. Bioresour. Technol. 2009;100: 5454-5460.

25. Bovea M, Ibáñez-Forés V, Gallardo A, Colomer-Mendoza F. Environmental assessment of alternative municipal solid waste management strategies. A Spanish case study. Waste Manage. 2010;30:2383-2395

26. Jha AK, Sharma C, Singh N, Ramesh R, Purvaja R, Gupta PK. Greenhouse gas emissions from municipal solid waste management in Indian mega-cities: A case study of Chennai landfill sites. Chemosphere 2008;71:750-758.

27. Weitz KA, Thorneloe SA, Nishtala SR, Yarkosky S, Zannes $\mathrm{M}$. The impact of municipal solid waste management on greenhouse gas emissions in the United States. J. Air Waste Manag. Assoc. 2002;52:1000-1011.

28. Abila B, Kantola J. Municipal solid waste management problems in Nigeria: Evolving knowledge management solution. Int. J. Environ. Chem. Ecol. Geol. Geophys. Eng. 2013;7:303-308.

29. Eneh OC. Managing Nigeria's environment: The unresolved issues. J. Environ. Sci. Technol. 2011;4:250-263.

30. Periathamby A, Hamid FS, Khidzir K. Evolution of solid waste management in Malaysia: Impacts and implications of the solid 
waste bill, 2007. J. Mater. Cycles Waste Manage. 2009;11:96-103. 31. Srivastava P, Kulshreshtha K, Mohanty C, Pushpangadan P, Singh A. Stakeholder-based SWOT analysis for successful municipal solid waste management in Lucknow, India. Waste Manage. 2005;25:531-537.
32. Perron GM, Côté RP, Duffy JF. Improving environmental awareness training in business. J. Clean. Prod. 2006;14:551-562.

33. Kaosol T. Sustainable solutions for municipal solid waste management in Thailand. World Acad. Sci. Eng. Technol. 2009;60: 665-670. 